\title{
11 Global Pressures: Multinational Corporations, International Unionism, and NGOs
}

\section{THE GLOBALIZATION CHALLENGE}

The globalization of product, financial, and labor markets has made it easier for companies to produce many of the goods and services they sell wherever in the world the right skills can be found at the lowest cost. The desire to sell products worldwide has also created incentives for firms to have a presence in multiple countries. Together these facts have made labor relations in many industries global in scope. Globalization is of particular importance to emerging countries. Nearly 50 percent of the world's manufacturing employment is now located in emerging countries. ${ }^{1}$

Globalization poses significant challenges to labor relations practices. Historically the laws, markets, institutions, norms, and practices of labor relations have developed on a national basis. Globalization has weakened, though not eliminated, the role of national systems of labor relations and given rise to a number of new institutions, structures, and processes for dealing with all of the labor relations functions discussed in previous chapters.

In this chapter we will discuss these new arrangements and the challenges globalization poses to labor relations. To do so we will use the framework laid out in chapter 1 for analyzing labor relations.

\section{THE EFFECTS OF EXPANDING MARKETS}

A key argument put forward by John R. Commons, one of the early theorists in industrial relations, was that as products and labor markets expanded in 
scope, unions and other institutions also needed to expand if they were to "take wages out of competition" by standardizing wages in labor markets in which they worked. ${ }^{2}$ As markets expanded from local to national levels, so did unions, labor laws, and management policies and practices. Commons argued that failing to expand union coverage to the larger market would reduce workers' bargaining power and put downward pressures on wages, what some now call a "race to the bottom." Firms would move work to lower-wage regions or workers who were willing to work for wages below accepted rates in a community (or nation) would migrate to take jobs at lower rates.

Another environmental change-advances in communications technologies - also promoted globalization of employment, especially in services. Call centers, editing, accounting services, tax preparation, radiology (X-ray reading), legal research, and document management are among the many services that are now available on a global basis " $24-7$.'

Demographic trends also support the globalization of work. Emerging countries have added a significant number of workers to the global labor force in recent years, increasing competition in the labor market for work (see the discussion in chapter 4). As education and skill levels increase in emerging countries and/or immigration rules are eased, competition for work at all occupational levels will continue to increase.

\section{The Globalization of Business Strategies}

This competitive process is now playing out on a global basis among multinational firms. Over the last fifty years the number of multinational corporations (MNCs) has increased greatly, to the point that they now have a major impact on world commerce and the conduct of labor relations in nearly every country.

Every MNC must make strategic choices about where to locate different parts of their business and supply chain. This brings into play the role of business strategies as a key factor shaping labor relations in developing countries. One key variable that influences the business strategy of an MNC are the wage levels at various potential production sites and countries. Although access to resources and markets also influence business strategies, the expansion of trade and the increase in the number of MNCs has led to a steady movement of manufacturing and service work from higher-wage countries to lower-wage countries and regions, and this movement is of special interest and importance to emerging countries. Box 11.1 illustrates the evolving business strategy of Nike, one of the early firms to globalize its production of apparel and athletic equipment. ${ }^{3}$ 


\section{BOX 11.1}

\section{Nike's Global Business Model}

Nike started operating as a company in 1964. Early on, its business model called for its products to be designed and marketed in the United States and manufactured abroad. First, it located manufacturing facilities in Japan. As Japan's labor costs rose and Nike's business expanded, the company moved production to Korea and later to lower-cost countries such as Indonesia, Vietnam, China, and parts of Latin America.

Nike did not own or manage the factories that produced its products. Instead, it contracted with supplier companies located in these various countries. In doing so, Nike and other firms that followed a similar strategy developed global supply chains. Today 600 contractors in forty-six different countries around the world supply Nike with products (http://nikeinc.com/pages/frequently-asked-questions).

The Nike story told in box 11.1 is similar to that of many other MNCs that have become household names, such as Siemens, Apple, General Electric, Zaras, and Hewlett Packard. Essentially all large firms that sell products that can be easily transported globally and/or that sell to global markets have global supply chains. The development of global supply chains offers strategic economic development and business opportunities to emerging countries and to companies that specialize in contract manufacturing. Countries across the globe (and individual firms) compete for contracts from MNCs and the jobs that go with them by offering the lowest cost that is consistent with a company's quality and delivery requirements. The effect of this is that competition in labor relations has become globalized.

\section{The Pressure of Diversity on MNCs}

Managing an MNC involves issues of cultural, legal, and institutional diversity. Workers from various cultures often view work differently, attach different meanings to work, and place different demands on their unions. ${ }^{4}$

Of course, management in any firm faces some diversity among workers in terms of their culture and attitudes toward work. Some workers are most concerned about their pensions, whereas others may be most concerned about their current income and pay little attention to deferred compensation. Some workers have strong work ethics and would like to work on their own, whereas others may need constant supervision. The extent of this cultural 
diversity widens, however, as the firm crosses national boundaries. As a result, for example, compensation policies that work in one country may be inappropriate in another. Or communication and motivation techniques that succeed in one culture will fail in another.

There is also wide diversity in the legal regulation of labor relations and employment conditions and the institutions that shape labor relations across countries (see chapter 3). In some countries, for example, national laws recognize workers' rights to form unions and strike, but in other countries unions are outlawed or are dominated by the government. In some countries, the national government extensively regulates the substance of employment conditions. The ideologies and forms of the labor movement also differ markedly across countries (see chapter 2). The structure of unions also differs markedly across countries (see examples in chapter 6).

\section{The Degree of Labor Relations Centralization in Multinational Corporations}

The multinational corporation faces control and coordination problems as a result of the wide diversity that exists across countries in culture, law, and institutions. The key decision for management that emerges from the diverse political and social institutions it faces in different countries is how much to centralize the direction of labor relations. At one extreme, labor relations management can be centralized in the corporate offices of the MNC. Alternatively, local management in each country in which the MNC operates can be allowed to independently direct labor relations. Management's problem is how to pursue companywide objectives through labor relations policies in the face of all the diversity that arises in the MNC.

Traditionally, MNCs have responded to this problem by maintaining a high degree of local control (decentralization) of labor relations. Analysts, in fact, generally conclude that the administration of labor relations of MNCs is more decentralized than other management functions, such as finance or marketing. ${ }^{5}$

MNCs found that there were substantial benefits to be gained from the decentralization of labor relations, including the ability to respond flexibly to the diversity discussed above. When local managers in each country where an $\mathrm{MNC}$ operates are allowed to shape labor relations policies, they can create policies and procedures that fit with local conditions and events.

In recent years, however, MNCs have begun to centralize their control and administration of labor relations. Centralization of a corporate function has always had the advantage of providing consistency and economies of scale. However, in the past, the great diversity of many local environments has made it difficult to implement consistent policies. 
Why, then, the switch to more centralized control? The explanation appears to lie in the fact that MNCs are becoming more global in their strategies and organizational form. The emergence of global firms has led management to strive to integrate their internal operations and policies. When production is integrated, for example across national boundaries, it makes less sense for the MNC to maintain wide variations in its labor relations policies. The opening of trade through mechanisms such as the European Union and the North American Free Trade Agreement and the formation of other regional trading blocs has contributed to globalization and provides further impetus to MNC's to coordinate labor practices across their global supply chains.

This trend provides another illustration of one of the central themes of this book - namely, that managements are increasingly striving to link labor relations more closely to business strategies. Increased globalization further encourages MNCs to develop particular business strategies and then align their production and labor relations systems with those business strategies. This is not very different from the factors encouraging greater centralization in domestic firms. The special dilemma for labor relations managers in MNCs, however, is that culture, law, and institutions in many countries around the world shape labor relations at the same time that globalization has increased the premium on coordination and centralization.

The literature on human resources at MNCs also provides evidence of how national institutions (i.e., laws and public policies) constrain the influence and spread of MNC practices; corporations find that they must conform to national and in some cases local institutional constraints and/or pressures. Some of the literature suggests that instead of MNCs bringing standardization in workplace practices across countries, it is MNCs that have to bend and modify their practices to fit institutional constraints and pressures. There is evidence that the intersection of MNC and country-specific institutions leads to "hybridization"- practices and forms of organization that are a blend of the practices of the home country of the MNC and the practices common in the country where the MNC operates. At the same time, studies of the labor relations practices of MNCs consistently reveal a strong effect from the MNC's country of origin. ${ }^{6}$

\section{The Globalization of Labor Relations and Human Resource Management: The Case of Colgate-Palmolive Corporation}

Colgate-Palmolive (C-P) is an American-based multinational consumer products firm that has over 100 manufacturing facilities in thirty different countries. It offers a good case study of how a large MNC has restructured its global labor relations activities in recent years.? 
The sales and financial performance of C-P has been quite strong over the last ten years, and a key to their success is that the company, which historically had been more global in orientation than its competitors, has become even more globally focused. International sales now account for most of the company's profits. In addition, the company has promoted a greater regional focus in its manufacturing and marketing operations, in part due to the regional trade pacts that have been reached in recent years and other pacts that are expected in the near future in regions including Latin America and Asia.

Regional trade pacts have helped spur a movement toward regional "centers of excellence" through manufacturing consolidation, and the company has moved away from its practice of having more than one plant within a region (and, in some cases, within a country) produce the same product. Manufacturing consolidation was also facilitated by technological improvements that made it possible to produce greater volumes in a single plant and organizational (and labor relations) changes that allowed for three-shift-a-day, seven-day-a-week production.

There was also a move toward a more simplified global supply chain (i.e., more global sourcing and fewer preferred suppliers) and less product variety across countries (less "tinkering" with the product). C-P has moved toward more globally similar products to take advantage of economies of scale in production and standardization of marketing. In addition, the ease with which consumer information now moves across countries is leading C-P to seek greater central control of marketing and products. These trends are all leading to greater regional and global coordination in the MNC's internal staff operations.

An increasingly global focus and structure first appeared in the internal functioning of C-P's human resource management and labor relations. In C-P's plants outside the United States, there is no clear separation between "labor relations" and "human resource management." (This is also true for other MNCs.)

C-P's human relations and labor relations decision making traditionally has been decentralized; most decisions were made by facility managers or factory managers in facilities. Inside the company, there were countrylevel presidents and directors of manufacturing who became involved in facility issues only when there was a crisis in the corporation's traditional way of operating. In addition, there was a small corporate staff (a vice-president of human relations and a vice-president of labor relations) in the United States at the company's corporate headquarters in New York City that provided strategic guidance to country- and facility-level managers on labor relations and human resource matters. But often these corporate managers did 
not become involved in plant-level labor relations matters until a new labor agreement was being negotiated (and even then their input was only advisory) or when a strike or some other emergency was occurring. On an everyday basis, local managers controlled the labor relations function.

C-P's corporate managers decided that there was a need to move away from this extreme form of decentralization of labor relations because of the corporation's increased need for coordination in the context of the increasing role of the company's global supply chain. In addition, the integration of trade and the creation of several new "centers of excellence" in the late 1990s led to a consolidation of the company's production system that was accomplished by closing a number of facilities and increasing output flows through increased mechanization and full-day and full-week operations in the plants that remained. One consequence of production consolidation and increased trade flows was that a labor disruption at a center of excellence would produce greater harm for the company's sales and profits than had been the case in the past. Corporate managers wanted to have more control of these disruptive events and engage regional human resource and labor relations managers in efforts to minimize their occurrence altogether and minimize the effects of the disruptions that did occur.

A mix of union and nonunion plants had evolved at C-P, and much of the corporation's growth occurred in nonunion plants. Consolidation has been occurring disproportionately in unionized facilities in recent years, in part because unionized plants also tend to be older plants.

In an effort to achieve more coordination and consistency across the corporation and greater interaction between human resources and labor relations managers and those involved in operations, C-P created (or expanded) regional human resource offices and gave them more direct involvement in plant-level labor relations activities. To improve the quality of human resource and labor relations inside $\mathrm{C}-\mathrm{P}$, a series of regional workshops were launched that involved the company's top manufacturing and human resource and labor relations staff. The goals of these workshops were to (1) increase the regional focus across the company's operations; (2) increase coordination between the manufacturing and human resource (and labor relations) staff inside the company (these groups had rarely met together in focused meetings in the past); and (3) teach a standard and strategic approach to setting key work rule and operations objectives in all (unionized and nonunion) facilities. Subsequently, related training programs were launched to help C-P managers acquire a more global perspective.

Middle and shop-floor managers at C-P are now expected to convey the company's labor relations goals and the methods that can be used to 
implement its global human resource and labor relations objectives. This is accompanied by workforce training programs that focus on instilling an appreciation for the increased need to make adaptive changes in the workplace.

The various business units in $\mathrm{C}-\mathrm{P}$ are now required to use a standardized "strategic labor relations process" to guide the preparation for, process of, and evaluation of collective negotiations (in unionized settings) and employee relations objectives (in facilities where employees are not represented by unions). The process includes a country-level planning meeting to set labor relations objectives; submission of those objectives for division approval; a strategically oriented negotiations process accompanied by an appropriate communications strategy; and subsequent evaluation of the overall process. Both bargaining objectives (which typically involve work rules and work processes) and compensation objectives are identified and then the parties are expected to consider how those objectives support one another. This process takes place with the guidance of a corporate global labor relations strategy developed by top manufacturing and human resource managers. A key outcome of this process is that various human resource performance metrics are now collected and compared across plants. The hope is that this data and the ensuing comparisons of plant performance will influence the objectives that are set in the strategic labor relations process that guides labor negotiations or the formation of employee relations objectives.

Additional steps have been taken in other parts of C-P's human resource and labor relations internal function to stimulate more regionally and globally coordinated operations. For example, the company introduced software to handle employee personnel records that enables employees to easily access their records so they can monitor and make changes in their personnel profile (e.g., when their family status changes because of events such as marriage or the birth of a child). The corporation also introduced shared information services that included centralized call centers to handle employee requests. This move was facilitated by the fact that there was increasing similarity in the nature of the business and technologies in the company's various business units, spurred in large part by the increased role of the company's global supply chain.

At C-P's central corporate, country, and plant levels, increased attention is now paid to working conditions throughout the company's global supply chain. The company conducts a regular audit of labor practices at all of its supplier plants and the plants it directly operates that includes the monitoring of pay levels and work time and efforts to eliminate any child labor. In this respect, $\mathrm{C}-\mathrm{P}$ is addressing issues that have received considerable attention in 
relation to other MNCs. We will take these issues up in a later section of this chapter.

\section{Impacts on the Middle Tier of Labor Relations Processes}

The processes taking place at Colgate-Palmolive illustrate how one large organization is adjusting to globalization. For all organizations, globalization is raising questions and issues related to the functional level of labor relations as it is managed across global suppliers and contractors of multinational firms. These questions include:

- Which employer is responsible for labor practices in global supply operations? Is it the MNC or the local supplier? More generally, should an MNC have an explicit global labor strategy and set of principles, and if so what should these be and how should they be monitored and enforced?

- What standards should govern practices given that there is great variation in content; the level at which standards are set for issues such as minimum wages, overtime, child labor regulations; and the quality of enforcement of labor and employment laws in emerging countries?

- Who, if anyone, represents workers in global supply chains? Unions are largely organized at the country level and have not expanded to serve workers across national boundaries. In addition, the level of unionization, as noted in chapter 6 , is very low in many emerging countries.

- What are the consequences of globalization on labor relations outcomes? Is it inevitable that globalization results in, as Commons predicted, a "race to the bottom" that lowers the standards of living in higher-wage countries and holds down wages and working conditions in low-wage countries or does globalization support economic development and improved employment outcomes in emerging nations?

\section{MANAGING A GLOBAL SUPPLY CHAIN AND LABOR PRACTICE POLICIES}

Consider Nike's history in dealing with these key questions. Initially, Nike, like many other MNCs, argued that the labor practices of its global suppliers were not its responsibility. As worker activists brought media attention to abuses of child labor and unsafe working conditions, pressures mounted on Nike to question and ultimately to revise its view. In the mid-1990s, Nike company leaders noted that there was a direct correlation between the 
growing number of media accounts of poor labor practices and conditions in its supply chain and the company's falling stock price. In 1998, Nike's CEO Phil Knight famously said he was tired of the fact that "Nike's products have become synonymous with slave wages, forced overtime, and arbitrary abuse."

Nike changed its policies and practices and became an early leader in establishing corporate standards for its supply change. It established an internal Corporate Social Responsibility Unit and charged it with creating a code of conduct that would be used to monitor and evaluate the extent to which its suppliers are meeting the standards in its code of conduct. Eventually the company made public the locations where its products are made. Box 11.2 reproduces Nike's Code of Conduct. Other large MNCs have followed a similar path. Unfortunately, too often it has taken a tragic accident to motivate companies to do so. Apple's largest manufacturer in China, Foxconn, experienced suicides and considerable unrest in its factories before Apple began to actively monitor and seek to improve operations in its supply chain. The most visible and largest tragedy to date occurred in the collapse of an apparel factory in Bangladesh in 2013 (discussed in box 9.3).

BOX 11.2

\section{Nike's Code of Conduct}

\section{Employment is voluntary}

- The contractor does not use forced labor, including prison labor, indentured labor, bonded labor or other forms of forced labor. The contractor is responsible for employment eligibility fees of foreign workers, including recruitment fees.

Employees are age 16 or older

- Contractor's employees are at least age 16 or over the age for completion of compulsory education or country legal working age, whichever is higher. Employees under 18 are not employed in hazardous conditions.

\section{Contractor does not discriminate}

- Contractor's employees are not subject to discrimination in employment, including hiring, compensation, promotion or discipline, on the basis of gender, race, religion, age, disability, 
sexual orientation, pregnancy, marital status, nationality, political opinion, trade union affiliation, social or ethnic origin or any other status protected by country law.

Freedom of association and collective bargaining are respected

- To the extent permitted by the laws of the manufacturing country, the contractor respects the right of its employees to freedom of association and collective bargaining. This includes the right to form and join trade unions and other worker organizations of their own choosing without harassment, interference or retaliation.

Compensation is timely paid

- Contractor's employees are timely paid at least the minimum wage required by country law and provided legally mandated benefits, including holidays and leaves, and statutory severance when employment ends. There are no disciplinary deductions from pay.

Harassment and abuse are not tolerated

- Contractor's employees are treated with respect and dignity. Employees are not subject to physical, sexual, psychological or verbal harassment or abuse.

Working hours are not excessive

- Contractor's employees do not work in excess of 60 hours per week, or the regular and overtime hours allowed by the laws of the manufacturing country, whichever is less. Any overtime hours are consensual and compensated at a premium rate. Employees are allowed at least 24 consecutive hours rest in every seven-day period.

Regular employment is provided

- Work is performed on the basis of a recognized employment relationship established through country law and practice. The contractor does not use any form of home-working arrangement for the production of Nike-branded or affiliate product. 
The workplace is healthy and safe

- The contractor provides a safe, hygienic and healthy workplace setting and takes necessary steps to prevent accidents and injury. arising out of, linked with or occurring in the course of work or as a result of the operation of contractor's facilities. The contractor has systems to detect, avoid and respond to potential risks to the safety and health of all employees.

Environmental impact is minimized

- The contractor protects human health and the environment by meeting applicable regulatory requirements including air emissions, solid/hazardous waste and water discharge. The contractor adopts reasonable measures to mitigate negative operational impacts on the environment and strives to continuously improve environmental performance.

The code is fully implemented

- As a condition of doing business with Nike, the contractor shall implement and integrate this Code and accompanying Code Leadership Standards and applicable laws into its business and submit to verification and monitoring. The contractor shall post this Code, in the language(s) of its employees, in all major workspaces, train employees on their rights and obligations as defined by this Code and applicable country law; and ensure the compliance of any sub-contractors producing Nike branded or affiliate products.

Sources: http://www.nikeinc.com/system/assets/2806/Nike_Code_of_Conduct _original.pdf. See also Nike's Corporate Responsibility Report at http://www nikebiz.com/crreport/.

\section{Monitoring Compliance with Codes of Conduct}

Once a company creates a code of conduct, it must decide how to monitor and enforce it. Should the company do this itself, using audit teams staffed by members of the company's social responsibility units? Should it hire and pay consultants to audit its labor practices? Should it work with and allow NGOs to do the auditing? Should it audit operations on an unannounced basis or tell 
suppliers in advance when audits will be done? Should it coordinate its own audits with the audits of other MNCs that purchase goods from a given supplier to avoid having multiple firms using different standards and engaging in auditing operations at different times? And finally, what standards should apply-ones that are consistent with the host country's laws, norms, and competitive wage rates or companywide standards?

Some MNCs, such as Walmart, have sought to avoid working with NGOs and instead have hired consultants and professional engineering firms to monitor suppliers. Others use a combination of internal auditors, consultants, and NGOs. Still others work together and with global labor organizations to perform auditing and training functions. We will discuss the roles NGOs play in these processes in more detail later in this chapter.

The effectiveness of corporate audits is one of the most hotly debated issues in the field of labor relations today. The results of the best research on this topic indicate that when rates are arrayed on a scale of 0 to 100 percent compliance with the standards in corporate codes of conduct, the average rate tends to peak slightly above 50 percent. Moreover, few plants appear to be on a path of continuous improvement toward 100 percent compliance. Instead, over time some plants experience declines in compliance scores and improvements.

Some plants do better than others on a consistent basis. Plants located in countries with strong laws governing labor and other business practices tend to have higher compliance scores. So do plants that have longer-term contracts with MNCs and plants where there is more management interaction and sharing of expertise on best practices in lean manufacturing and advanced HRM systems. ${ }^{9}$ However, the fact that periodic inspections of building safety do not ensure that workplaces are truly safe is well illustrated by the examples provided in a New York Times account of the steps managers at numerous garment factories took to avoid and manipulate the inspection/audit process (see box 11.3).

\section{BOX 11.3}

\section{Fast and Flawed Inspections of Factories Abroad}

Inspectors came and went from a Walmart-cetified factory in Guangdong Province in China, approving its production of more than $\$ 2$ million in specialty îtems that would land on Wangrt's shelves in time for Christmas. 
But unknown to the inspectors, none of the playful items, including reindeer suits and Mrs. Claus dresses for dogs, that were supplied to Walmart had been manufactured at the factory. Instead, Chinese workers sewed the goods - which had been ordered by the Quaker Pet Group, a company based in New Jersey - at a rogue factory that had not gone through the certification process set by Walmart for labor, worker safety or quality, according to documents and interviews with officials involved.

To receive approval for shipment to Walmart, a Quaker subcontractor just moved the items over to the approved factory, where they were presented to inspectors as though they had been stitched together there and never left the premises.

Soon after the merchandise reached Walmart stores, it began falling apart.

Fifteen hundred miles to the west, the Rosita Knitwear factory in northwestern Bangladesh-which made sweaters for companies across Europe-passed an inspection audit with high grades. A team of four monitors gave the factory hundreds of approving check marks. In all 12 major categories, including working hours, compensation, management practices and health and safety, the factory received the top grade of "good." "Working Conditions-No complaints from the workers," the auditors wrote.

In February 2012, 10 months after that inspection, Rosita's workers rampaged through the factory, vandalizing its machinery and accusing management of reneging on promised raises, bonuses and overtime pay. Some claimed that they had been sexually harassed or beaten by guards. Not a hint of those grievances was reported in the audit. . .

An extensive examination by The New York Times reveals how the inspection system intended to protect workers and ensure manufacturing quality is riddled with flaws. The inspections are often so superficial that they omit the most fundamental workplace safeguards like fire escapes. And even when inspectors are tough, factory managers find ways to trick them and hide serious violations, like child labor or locked exit doors. Dangerous conditions cited in the audits frequently take months to correct, often with little enforcement or follow-through to guarantee compliance.

Supply chain experts and monitors say that far too often, factory managers play cat-and-mouse games with inspectors because they are desperate to avoid a failing grade and the loss of a lucrative stream of orders. 
The experts provided real-life examples. To avoid appearing illegally overcrowded, one factory moved many machines into trucks parked outside during an inspection, a monitor said. Whenever inspectors showed up at certain plants in China, the loudspeakers began playing a certain song to signal that underage workers should nan out the back door, according to several monitors. During inspections in India, some factories displayed elaborate charts detailing health and safety procedures that, like stage props, were transferred from one factory to another, another monitor said. ...

Mr. [Auret] van Heerden [president of the Fair Labor Association] said, "You can never visit facilities often enough to make sure they stay compliant - you'll never have enough inspectors to do that. What really Keeps factories compliant is when workers have a voice and they can speak out when something isn't right."

Source: Reprinted from Stephanie Clifford and Steven Greenhouse, "Fast and Flawed Inspections of Factories Abroad," New York Times, September 3, 2013.

The evidence on the positive but limited effects of corporate codes of conduct has led to active debates about what else needs to be done to improve labor conditions in global supply chains. ${ }^{10}$ Meetings of the multiple stakeholders involved-MNCs, NGOs, unions, government officials, ILO representatives, and academics - have been held at various universities to seek consensus on how to improve monitoring and compliance with codes of conduct, but to date no clear consensus has emerged. One big problem that remains is that a root cause of the pressure to violate labor standards comes from the purchasing and sourcing staff of MNCs. Pressure to deliver products that have short life cycles (e.g., a particularly popular style of shirts or shoes or the newest iPad or similar electronic device) quickly reverberates down through the supply chain to contractors, who conclude that they have no choice but to pressure their work force to meet the schedule. Not surprisingly, violations of hours rules-forced overtime, long hours, shorter meal and rest breaks, and fewer days off-are among the most frequent violations of codes of conduct.

INTERNATIOMAL (FREE) TRADE AGREEMENTS

Increased international trade also has been spurred in recent years through various regional and international trade agreements. Our review of several of 
those agreements in this section focuses on the concerns about labor rights and labor conditions that surfaced during debates about these agreements and the provisions that were included in them to address those concerns. We focus on the three trade agreements the United States made with Canada and Mexico, Jordan, and Colombia.

\section{NAFTA}

The North American Free Trade Agreement (NAFTA) linking Canada, the United States, and Mexico, which took effect in January 1994, removed tariffs and other trade barriers among the three countries over a fifteen-year period. Both the passage and the continuing effects of NAFTA have been extremely controversial. NAFTA has been widely criticized by labor unions, who claim that Mexico's low wages have enticed many U.S. firms to relocate south of the border. Meanwhile, environmentalists worry that companies flee south in order to take advantage of weak pollution controls and lax enforcement of environmental regulations. Presidents Clinton, Bush, and Obama; the U.S. business community; and many economists, on the other side of this debate, support NAFTA on grounds that it provides gains to all three countries through trade. NAFTA supporters also claim that it will help integrate Mexico more fully into the world economy and thereby address Mexico's social problems and their spillover effects in the United States (such as high immigration and the drug trade). To address its critics, side agreements were added to NAFTA concerning the environment and labor rights. The side agreements related to labor created national administrative offices that are authorized to investigate public charges that one of the NAFTA countries is not enforcing its own labor laws.

\section{The U.S.-Jordan Free Trade Agreement}

In the U.S.-Jordan Free Trade Agreement of 2001, both countries made pledges related to "reducing barriers for services, providing cutting-edge protection for intellectual property, ensuring regulatory transparency, and requiring effective labor and environmental enforcement." 11 The effects of this treaty in Jordan were significant. American companies such as Walmart and Target quickly established stores in Jordan, and in the first year after the trade agreement was agreed, Jordan increased its exports by 213 percent.

The U.S.-Jordan agreement was the first free trade agreement between the United States and a foreign country that directly included labor provisions in the text of the agreement itself. In the agreement, both countries agreed to 
comply with the statutes embodied in the ILO's Declaration on Fundamental Principles and Rights at Work and to enforce their own domestic labor laws. ${ }^{12}$ Moreover, the free trade agreement established dispute resolution procedures and trade sanctions to be used if either country was seen as violating its domestic labor laws.

However, although these provisions were hailed by the labor and environmentalist communities, the U.S. government's policy with regard to enforcing the labor provisions of the agreement became much more pro-business when George W. Bush became president. In 2001, newly installed U.S. trade representative Robert Zoellick and the Jordanian ambassador to the United States announced that both the United States and Jordan had agreed not to resort to trade sanctions and that neither country would use the dispute resolution enforcement procedures outlined in the free trade agreement if they would block trade. Consequently, the labor provisions that had been hailed as revolutionary in this agreement were not implemented. ${ }^{13}$ In addition, after the implementation of the free trade agreement in 2001, Jordan passed a Public Assembly Law and other legislation that limited freedom of association and collective negotiations.

In 2006, the National Labor Committee (an NGO) testified to the U.S. Congress that labor laws were not being enforced in Jordan and provided evidence that the Jordanian garment industry had sweatshops where workers worked 20-hour days, were not paid consistently, and suffered emotional and physical abuse. These companies employed migrant workers from China, Sri Lanka, and Bangladesh who were being forced to work as de facto involuntary servants.

\section{The U.S.-Colombia Trade Agreement}

The U.S.-Colombia Trade Promotion Agreement came into force in May 2012. ${ }^{14}$ The agreement states that both the United States and Colombia will continue to maintain in domestic law the right to freedom of association (the right to form and join a union) and the right to engage in collective negotiations and will fulfill promises that all forms of forced and child labor will be eliminated.

Observers claim that, as in Jordan and Mexico, the labor rights provisions in the Colombia trade pact have proven to be ineffective. Allegations surfaced that since 2010, 104 labor and human rights activists have been murdered in Colombia. Furthermore, the Congressional Monitoring Group on Labor Rights provided extensive documentation showing that the right to organize and engage in collective negotiations was being curtailed and undermined in Colombia. ${ }^{15}$ 


\section{The Controversy Surrounding Trade Agreements}

These three trade agreements make clear that a great deal of controversy exists about the real impacts of trade agreements on worker rights and work conditions. Defenders of these agreements argue that higher levels of trade ultimately lead to higher rates of economic growth in emerging countries and improvements, even if they are gradual, in wages and work conditions. Critics, on the other hand, claim that trade pacts encourage MNCs to leave countries where wages and work conditions are better. And these critics allege that even in the emerging countries, any growth in employment largely occurs in low-wage sectors, often at the expense of already existing indigenous (and frequently more craft-oriented) production.

\section{LABOR RESPONSES TO THE POWER ADVANTAGE OF MULTINATIONAL CORPORATIONS}

The expansion of economic activity across national boundaries creates a disadvantage in bargaining power for workers and unions. Multinational operation allows management to move production and capital across national borders and increases the competition for jobs among workers. Imagine, for example, the pressures highly paid Western European (or North American) workers experience when MNCs operating in their countries can shift production to countries where workers receive hourly wages that are a fraction of those received in Western countries and where environmental and other social regulations are weaker. This is what unionists refer to as "social dumping." When management faces a strike in its operations in one country, it can gain leverage during the bargaining process if it can turn to alternative production facilities in other countries or substitute workers in other countries for those who are out on strike.

In theory, one way a union could counter the advantages management gains from the expansion of markets is to expand the union's jurisdiction so that it is coextensive with the boundaries of the multinational. This is how unions in the United States and a number of other advanced industrialized countries expanded their jurisdiction. They shifted from local or regional unions to become national unions as the product markets the companies they worked for grew national in scope. If this were accomplished, the resulting multinational unions would be better able to remove competition across workers in the different locations where the MNC operates. How successful have unions been at following a similar strategy and becoming multinational? This section examines that issue. 
Even though there are some examples of multinational unions or at least policies to coordinate national unions, these examples are few. Let us consider why this has been so and then look at some counterexamples.

\section{Union Difficulties with Operating at the Multinational Level}

Unions have found it difficult to become multinational because of the wide diversity that exists across countries in culture, law, and institutions. It is difficult enough for a union operating in one country to maintain cohesion and solidarity among its members. When the economic and cultural differences, communication difficulties, and fears that exist among workers in different countries are added to the normal problems of unions, maintaining solidarity becomes a nearly insurmountable problem.

Consider the problems that multinational operation creates for union solidarity in both emerging and highly industrialized countries. Workers in an emerging country, who earn low wages and face few employment alternatives, are generally very reluctant to support the bargaining demands of their high-wage counterparts in an advanced industrialized nation. There are strong short-run incentives for the workers in these two countries to view each other as competitors.

Imagine how difficult it is for a union to communicate with its members if those members speak a variety of languages. In addition, the managers in an MNC typically have a lot of information about company objectives and worldwide activities, whereas workers and unions are often hard pressed to gain information about such activities.

Mergers of independent unions across national borders has not been a solution to multinational pressures. Merging independent unions is difficult enough even in a single country where there are strong bargaining power advantages to be gained. Even greater impediments exist for such a merger if it were to involve two unions based in different countries that represent workers at the same MNC.

It is quite likely that the structure of two unions that might consider merging would not be similar even if the workers were employed by the same firm. Similar problems would exist even if these unions were to merely work to coordinate their bargaining demands.

Yet even given these difficulties, examples of cross-national union solidarity and support can occur short of mergers or coordinated bargaining. We examine efforts to build cross-national union solidarity below.

Cross-border union strategies have taken many different forms. The strategies are different for a Thai garment worker or a German metalworker or a 
U.S. retail worker. Industry, company, union structure, political traditions, ideology, levels of bargaining power, and differing sets of goals all affect how cross-border union activities are structured.

\section{The Role of International Trade Secretariats}

A number of international trade secretariats exist that provide information to member unions and coordinate activities across national borders. These are autonomous agencies that cover particular industries or groups of industries. The International Metalworkers Federation, one of the most active of these secretariats, includes members from many emerging countries and highly industrialized nations. Among its many activities, it issues research reports to its members.

Many of the secretariats have a close working relationship with the International Confederation of Free Trade Unions (ICFTU), which includes affiliated unions that represent 48 million workers around the world. The ICFTU includes only non-communist unions. The World Federation of Trade Unions (WFTU) at one time represented 134 million workers in the Communist unions that were affiliated with it. While the expansion of global trade is leading unions around the world to communicate more extensively with unions in other countries, the political differences that have traditionally separated these federations and many of their member unions have impeded coordination among these and other union federations.

\section{Cross-Border Union Alliances}

A number of unions have attempted to overcome these communications and political differences and have extended their reach around the world, either on their own or by forming alliances across national unions. Airline pilots have the most fully established international body. It is composed of 100 national-level pilots' unions/associations and has a combined membership of approximately 100,000 pilots (see box 11.4).

BOX 11.4

The International Feleration of Airline

Pilots Associations (IFRLPA)

The mission of IFALPA is to be the global voîce of professional pilots by providing representation, services and support in order to promote the highest level of aviation safety worldwide. 
This goal is realized through our core function which is to represent our members by:

Interacting with international organizations to achieve the highest level of aviation safety.

Developing common policies and positions and promoting the adoption of such policies by ICAO, regulatory authorities and the State of each Member Association.

Promoting and enhancing the role and status of professional pilots in ensuring the safety of the aircraft and well being of passengers and goods entrusted to their care.

Promoting a viable and expanding air transport industry.

Providing training and education for the benefit of professional pilots.

Providing Member Associations with services as needed.

Assisting in the organisational development of Member Associations.

Supporting Member Associations by providing expertise in the areas of Technical, Safety, Regulation and Industrial issues.

Facilitating the exchange of information and the co-ordination of activities amongst Member Associations and Pilot Alliances through various forums such as Conferences, Regional Meetings and Standing Committees.

Source: International Federation of Airline Pilots' Association, http://www .ifalpa.org/, accessed Nov. 15, 2013.

\section{Cross-National Union Strategies and Pressure Campaigns}

Similar cross-border networks or formal agreements to coordinate when needed in order to offset the power of MNCs have occurred in other industries as well. One prominent example was formed in 2008 that involved the United Steelworkers (based in North America) and UNITE (based in the United Kingdom). Box 11.5 summarizes the goals of their joint effort, called Workers Uniting. To date, these unions have supported each other in strikes involving companies that have operations in Britain and North America. 


\section{BOX 11.5}

\section{Workers Uniting-the Global Union}

Workers Uniting brings together Unite, the biggest union in the UK and Ireland, with the United Steelworkers, the largest industrial union in North America. Here are four reasons why this partnership is critical.

1. The economy is globalizing. From Brussels to Beijing, decisions about our economy are increasingly made far from home. A global union can provide us a voice in those decisions.

2. Politics is globalizing. Right wing politicians are using the same vicious tactics to undermine our livelihoods in the UK as they are in the U.S. and Canada. A global union can help us support progressive politics on both sides of the Atlantic.

3. Our employers are globalizing. A couple decades ago, only a few of our employers operated in more than one country. Now, nearly all of them do. A global union can help us stand up to our employers wherever they operate.

4. The movement is globalizing. Whether it's standing up for fair trade or fighting back against bank bailouts, progressive groups are mobilizing and uniting everywhere. A global union can help us join them in the fight for a better world.

Source: http://www.workersuniting.org/, accessed Nov. 15, 2013.

\section{Comprehensive Union Pressure Campaigns}

Unions have developed comprehensive or strategic campaigns in recent years that use a combination of research, rank-and-file activism, boycotts, and political leverage to bring pressure to bear on a company globally. These campaigns often target a single employer where workers have gone on strike, have been locked out, or are engaged in an organizing drive. They use indepth research to identify vulnerabilities in a company's global operations. Comprehensive union campaigns build coalitions with communities, NGOs, and other unions around the world to target the company's image, its suppliers, or its customers globally and to pressure the company to improve labor conditions.

The 1986 Shell Oil boycott was one of the earliest truly global comprehensive campaigns. Using the consumer boycott as its central tactic, the campaign 
against Shell linked anti-apartheid activists, trade unionists, civil rights activists, politicians, church activists, and consumers in a global divestment campaign. The United Steelworkers in North America have used these types of campaigns extensively to pressure global multinational companies such as BASF, Ravenswood, Bridgestone/Firestone, and Goodyear to end strikes and lockouts and to support collective negotiations campaigns. This approach is not limited to North American unions. Central American banana workers, European dockworkers, and Taiwanese telecommunications workers have all used cross-border campaigns in recent years.

However, while many campaigns have been successful, this type of global coordination and comprehensive campaigning requires large amounts of resources, funding, and long-term trust between unions. Companies have threatened unions with lawsuits for engaging in these types of campaigns, and weak transnational labor standards have made it difficult for unions to enforce gains that have been made.

\section{Cross-Border Union Networks}

Union networks are groups of unions at a shared multinational employer that come together to create a transnational structure for the purpose of sharing information, coordinating activity, and bargaining with an employer on a transnational level. Networks first appeared in the 1970s and have been promoted by global union federations (GUFs) as a way for unions to overcome the imbalance in bargaining power that unions of workers for multinational employers experience. Networks create long-term relationships between unions that have enabled unions to share information about a common employer, to act as infrastructure during cross-border campaigns, and to act as decision-making bodies that can bargain with employers on a transnational level.

Dozens of networks have been established in the auto, chemicals, food, and service industries. Networks of unions of employees at companies such as Carrefour and Arcelor have been able to sign agreements with employers on a transnational level such as international framework agreements (IFAs) that establish basic health and safety conditions and independent monitoring. Companies such as Volkswagen and Mercedes have created European-style works councils that meet annually with company management to discuss working conditions and compliance with basic ILO conventions. Finally, unions of employees at companies such as Gerdau and Sodexo have used networks as infrastructure during global campaigns. Unions in Brazil in particular have used networking as a strategy to coordinate bargaining nationally and establish transnational links with unions in the company's home country. 
However, challenges remain. National differences with regard to labor laws, language and communication issues, and weak transnational legal regulations have hampered attempts to build long-term union network structures.

\section{Sweatshop/Garment/Apparel Campaigns}

In the 1970s, sweatshops to produce garments reappeared in Latin America, the Caribbean Basin, Southeast Asia, and southern California. At that time, nations reeling from debt crises and structural adjustment programs turned to export processing zones for growth strategies. These zones are tax-free havens where MNCs can assemble low-value products such as garments, textiles, electronics, and toys with a low-wage-earning, mainly female workforce. Aided by free trade agreements and a system of subcontracting and global production, sweatshops became a prevalent source of supply for many high fashion apparel lines in the developed world and the embodiment of a race to the bottom for emerging countries.

Workers, mainly young women, organizing in countries such as Guatemala, Sri Lanka, Thailand, and Haiti have used global solidarity campaigns as a means of winning improvements in individual garment factories and increasing pressure for industry-wide and retailer-wide codes of conduct. These campaigns bring together a broad group of actors, including garment workers and unions, transnational NGOs, labor union allies, consumer activists, and North American university students.

Two factors are unique to organizing in the apparel industry. First, many of the products produced in the apparel factories of Latin American and South Asia are sold to consumers in North America and Western Europe. These consumers created an opportunity for garment workers to make alliances with unions and consumer groups in advanced industrial countries and create publicity about their working conditions. Second, as with the example of Nike discussed earlier in this chapter, many factories in emerging countries are actually subcontractors for large companies that produce well-known brand names and are headquartered in advanced industrial countries, such as Benetton, Disney, and Reebok. Because of the disparity between the high cost of luxury apparel in advanced industrial countries and the poor conditions of workers in emerging countries, garment worker campaigns have often relied on publicity that links well-known retailers such as the Gap and Walmart to poor working conditions in emerging countries in order to create enough consumer pressure to convince the retailers to assist in efforts to improve working conditions in garment factories. 
In addition, because many universities have large contracts with athletic companies such as Adidas and Nike, U.S. college students have become key supporters of these campaigns through groups such as United Students Against Sweatshops (USAS).

Some unions have promoted international framework agreements as effective structures. IFAs are multilateral agreements that are signed between a corporation and a union, usually one of the global union federations, in order to ensure equal standards across a multinational corporation. IFAs establish core labor standards such as the abolition of child labor, nondiscrimination, and freedom of association. They attempt to cover all employees, including workers who are subcontracted or are employed by subsidiaries and suppliers of the firm, and are designed to establish an institutionalized relationship with the firm at the headquarters level to ensure some form of monitoring and a process for improving working conditions. Even though some unions have had some success in getting companies to sign IFAs, these agreements are voluntary and are difficult to enforce due to a weak transnational regulatory environment.

\section{THE ROLE OF NGOS}

NGOs are now playing active roles in identifying abuses, lobbying for improved standards and enforcement practices, and in some cases actively representing workers and/or auditing labor conditions in supplier operations. Some NGOs are funded by employers. Some are funded independently by private foundations, individual donations, or labor unions. Some choose to work at arm's length with MNCs, some choose to work in collaboration with MNCs, and many implement both of these tactics. Various meetings have been held to bring together representatives of NGOs, unions, MNCs, and international organizations such as the ILO and the World Bank to try to learn from their experiences and about the research being done on global labor standards. But diversity of practices remains the norm. (See table 11.1 for examples of different NGO activities.)

\section{The Worker Rights Consortium}

One of the most active of these NGOs is the Worker Rights Consortium (WRC). The WRC has been involved in efforts to improve labor conditions at Foxconn, at apparel factories in Bangladesh, and at Nike. The history and role of the WRC is described in detail in box 11.6. 
Table 11.1. Examples of labor NGOs and their activities

Name

Activities

Fair Labor Association (www.fairlabor.org)

Social Accountability International (www .sa8000.org)

Worker Rights Consortium (www .workersrights.org)

United Students Against Sweatshops (www.usas .org)

China Labor Bulletin (www.clb.org.hk/en/)
Monitors factories independently and reviews company audits

Certifies compliance with codes of conduct

Reports on results of audits in participating companies

Governed by board of industry, NGO, and university representatives

Certifies that manufacturers are in compliance with SA8000 labor standards

Trains auditors

Provides self-assessment software for supply chains with recommendations for how to improve performance Lists factories that have achieved SA8000 certification Governed by mix of industry, NGO, and legal specialists

Investigates conditions in factories that sell licensed apparel to universities

Publishes periodic reports on factory conditions in different countries Maintains public database of factories supplying to universities

Governed by board of worker rights advocates consisting of university faculty and staff, students, and independent labor rights experts

Campaigns against abuses of workers' rights in factories that supply apparcl licensed by universities

Advocates for fair working conditions for university employees Led by student representatives from participating universities

Provides legal assistance to workers and labor organizations in China Conducts research on labor conditions in China

Maintains a Web site that provides information on strikes and collective bargaining in China

Led by professional staff

\section{BOX 11.6}

\section{Policing Workers' Rights in the Global Economy:}

\section{The Worker Rights Consortium}

The Worker Rights Consortium (WRC), a nonprofit organization started by the United Students Against Sweatshops in consultation with workers and labor rights experts, has become a watchdog for international sweatshop labor. The WRC was begun to help enforce the manufacturing codes of conduct adopted by colleges and universities; these codes ensure that factories that produce clothing and other goods bearing college and university names respect workers' rights.

The WRC has pressured universities to end their contracts with companies that do not comply with labor standards. For example, in 
March 2000, Brown University terminated its contract with Nike Inc., because of Brown's requirement that Nike comply with the university's licensing requirements and a monitoring system that is part of the WRC process. In its defense, Nike said that it had "serious concerns about the code and monitoring system included under the WRC" and that "the only effective way to make progress in improving factory conditions around the world is to have all stakeholders at the table." Nike claimed that the WRC was excluding industries and that it should be working with them instead.

The WRC at times has clashed with the Fair Labor Association (FLA), an independent group formed by the Clinton administration in 1999 to monitor the labor standards of overseas apparel manufacturers that sell their products to the United States. The FLA grew out of the Apparel Industry Partnership, a group of apparel manufacturers, consumer groups, and labor and human rights organizations brought to the White House in 1996. By 2000, over 100 colleges and universities had associated with the FLA so that they could be assured that clothing with their logos was not made in sweatshops. However, the WRC has criticized the FLA for being an industry-controlled monitoring system that only covers up sweatshop abuses and claims that only it, the WRC, can provide monitoring that is not swayed by corporate pressure.

Recently, however, the WRC and FLA have begun to forge a working relationship that includes working together on various monitoring projects. The WRC's membership now includes more than $100 \mathrm{col}-$ leges and universities.

Sources: "Nike Terminates Contract with Brown after University Seeks Compliance with Code," Daily Labor Report. April 4, 2000, A-2; and "Temple University Reviews Membership in 'Fair Labor' Apparel Monitoring Group," Daily Labor Report February 22, 2000, A-5.

\section{NEGOTIATING GLOBAL STANDARDS}

The challenge of creating negotiations structures and ongoing relationships in global operations has generated a number of different approaches. The most basic approach is to promote union representation on the shop floors of supplier operations by providing technical assistance to unions in emerging countries. The ILO is active in providing this type of technical assistance. In Cambodia, the ILO has developed a particularly extensive Better Factories 
Cambodia program that provides training, outreach, dispute resolution, and monitoring and disseminates information about best practices related to unions, collective negotiations, and labor standards. Reports on the program are quite positive. Rates of union representation in apparel plants range up to 50 percent and compliance with the labor standards in the ILO's code of conduct range between 70 and 95 percent. There continue to be reports of collusion and corruption among some employers and union leaders, however. This program has been sustained for over a decade in large part because of the continued support of the ILO and the Cambodian government. An independent evaluation of the ILO program has shown that the garment industry has continued to grow in Cambodia since the program was put in place and the firms that have complied with the employment standards the program monitors were more likely to survive over time than those that did not. ${ }^{16}$

While the Cambodian example is encouraging, it has yet to be replicated in other emerging countries, where unionization rates remain quite low and maintaining stable unions in industries and companies has proven to be difficult.

In some ways NGOs are a substitute for traditional unions. They have led efforts to publicize abuses of labor standards. They have negotiated with companies to improve working conditions in specific countries. Some have created sophisticated software programs that enable firms to evaluate the state of labor practices in their supply chains and receive advice about how to improve them. Others, such as United Students Against Sweatshops, have used consumer boycotts and lawsuits against highly visible brand-name companies such as Adidas and Nike to press them to end labor abuses among their contractors.

\section{BOX 11.7}

\section{NGOs That Conduct Union-Like Activities}

To improve working conditions in a number of countries, NGOs have emerged that include the direct negotiation of wages and other improvements in working conditions in their activities. Two prominent examples are found in India. We present them below as examples of the expanding role of NGOs in directly representing and bargaining on behalf of low-wage workers around the world.

In India, as in most emerging countries, the activities of a number of NGOs include some of the roles unions play in advanced industrial countries. One such organization is the internationally acclaimed SelfEmployed Women's Association (SEWA). Founded in 1972 by Nobel 
Peace Prize nominee Ela Bhatt, SEWA represents poor self-employed women in the rural and unorganized economic sectors of Intia. These women do not earn wages; they earn money through their own labor and small businesses. Dr. Bhatt's main goal for SEWA, which has over 960,000 members, includes trying to move them out of the informal sector, helping them gain full-time work, and improving the compensation and benefits women receive for their work, whether or not that work is in the informal sector. Essential facets of SEWA's activities are lobbying state and national governments to increase funding for social protection services, including health insurance and child care coverage; identifying microlenders; pressuring banks and other financial institutions to lower interest rates for first-time borrowers; and convincing financial institutions to provide more credit for women in business.

Another highly significant NGO/union in India is the Kagad Kach Patra Kashtakari Panchayat (KKPKP), also known as the Trade Union of Waste Pickers. The KKPKP represents waste pickers, waste collectors, and informal recyclers, all of which are part of the unorganized rural sector of the Indian economy. A key aspect of the KKPKP's role, like that of SEWA, is politically lobbying. KKPKP lobbies local municipalities and state governments to increase grants to the KKPKP's credit cooperative, which offers loans to members and provides a social security fund, so waste collectors have retirement funds. The KKPKP also helps members negotiate and bargain with local municipalities and private firms that hire waste collector workers. In April 2013, the KKPKP engaged in a sit-in strike in the city of Pune to protest the low wages waste collectors received.

In sum, India has numerous and multifaceted nongovernmental organizations, some of which perform critical union-like roles. Almost 60 percent of the Indian labor market consists of rural and informal sector workers, and these organizations represent workers in negotiations with government agencies and private sector employers. These NGOs help promote the emergence of an Indian middle class through advocacy, negotiations, protests, and political lobbying.

Sources: "About Us: History," Self-Employed Women's Association, http://www.sewa.org/About_Us_History.asp; "Initiatives," Kagad Kach Patra Kashtakari Panchayat, http://wastepickerscollective.org/index.php? $\bmod =$ page \&id=3; Leslie Vryenhoek, "KKPKP's Six-Day Protest Wins a Promise from Municipality," Inclusive Cities, April 11, 2013, http://www.inclusivecities .org/blog/kkpkps-six-day-protest-wins-a-promise-from-municipality/. 


\section{Summary}

This chapter began with Common's hypothesis that it would be difficult for unions to raise and standardize wages unless unions had a scope and jurisdiction that matched the expanding scope of product markets. MNCs have benefited from globalization because they take advantage of the efficiencies gained in global supply chains. The internationalization of production also shifts bargaining power in favor of MNCs in a number of ways. To date, no single institutional response or alternative source of power has been successful in counterbalancing this shift in power. Media exposure has been the most effective way to pressure MNCs to upgrade standards in their supply chains. However, this strategy has proven to be episodic. While media reports of tragedies or abusive work conditions do create a flurry of corrective activity, they tend to lose momentum fairly quickly after media coverage fades.

In general, consumers have not responded in consistent ways or demanded data on labor standards or avoided products of companies with reported labor standards problems. However, led by students organizing on college campuses into branches of USAS, successful consumer campaigns have been mounted that require MNCs that sell licensed athletic and sportswear bearing university logos to comply with NGO-specified labor standards.

Although codes of conduct have helped improve standards, they cannot, on their own, serve as a comprehensive strategy for achieving compliance or sustained improvements in labor standards in emerging countries. There is evidence that countries with stronger labor laws and enforcement practices have, on average, better wages and working conditions. The ILO's Better Factories Cambodia experiment suggests that a heavy infusion of incentives (lower tariffs or other trade restrictions), government and international pressures, and support for workplace-based unions can also have positive effects.

In addition, a number of cross-national union efforts have emerged, some of which involve international networks of unions and workers. Other union campaigns to pressure MNCs have linked with NGOs to make use of consumer and political pressure. Overall, it appears that achieving and sustaining acceptable work conditions in supply chains of MNCs will require a combination of the efforts of management, labor, NGOs, and governments, perhaps eventually reinforced by consumer purchasing behavior.

\section{Discussion Questions}

1. Why do international production opportunities and international trade generally advantage multinational corporations and disadvantage unions in terms of bargaining power? 
2. What factors led multinational corporations historically to typically prefer to decentralize their internal labor relations function, leaving most control of labor relations issues to local plant managers?

3. What recent factors/trends are leading many multinational firms to move toward more central coordination of their internal labor relations function?

4. Why is it so difficult for unions to forge cross-national alliances and launch successful cross-national pressure or bargaining campaigns?

5. Describe some of the basic steps you would take as the head of labor relations in a large multinational firm to make sure that work conditions are fair and defensible in your firm's global supply chain.

\section{Related Web Sites}

Colgate-Palmolive: http://www.colgate.com/app/Colgate/US/Corp/LivingOur Values/Sustainability/HomePage.cvsp

Cornell International Labor Relations School International Labor Standards: https:// www.ilr.cornell.edu/globalPortal/laborStandards/

Global Unions: Standing Together for the Rights of Unions: http://www.global -unions.org/?lang =en

Hewlett Packard Supply Chain Management: http://www.hp.com/hpinfo/ globalcitizenship/09gcreport/society/supplychain/strategy.html

Sustainable Business at Nike: http://nikeinc.com/pages/responsibility

\section{Suggested Supplemental Readings}

Bronfenbrenner, Kate, ed. Global Unions: Challenging 'Transnational Capital through Cross-Border Campaigns. Ithaca, N.Y.: Cornell University Press, 2007.

"Cross-National Perspectives on Multinational Companies and Employment Relations." Special issue of ILR Review 66, no. 3 (2013).

Locke, Richard M. The Promise and Limits of Private Power. Cambridge: Cambridge University Press, 2013.

Posthuma, Anne, and Dev Nathan, cds. Labour in Global Production Networks in India. New Delhi: Oxford University Press, 2010.

\section{Notes}

1. International Labour Organization and Better Factories Cambodia, "Thirtieth Synthesis Report on Working Conditions in Cambodia's Garment Sector and Statement of the Project Advisory Committee," July 18, 2013, http://betterfactories.org/?p=6706.

2. John R. Commons, "American Shoemakers 1648-1895: A Sketch of Industrial Relations," Quarterly Journal of Economics 24, no. 1 (1909): 39-98. See also Lloyd Ulman, The Rise of the National Trade Union: The Development and Significance of Its Structure, Governing Institutions, and Economic Policies (Cambridge, Mass.: Harvard University Press, 1958). 
3. For more on the history of Nike and evidence about labor conditions in global supply chains, see Richard M. Locke, The Promise and Limits of Private Power: Promoting Labor Standards in a Global Economy (Cambridge: Cambridge University Press, 2013). The material in this chapter draws heavily on this book and on the larger MIT-Stanford University Just Supply Chain research project.

4. See Jan H. Katz, "Cultural Issues in International Business," in The Handbook of International Business, ed. Ingo Walter and Tracy Murray (New York: Wiley, 1988), 11-1-11-17.

5. For recent research on how MNCs intcrnally structure and operate their labor relations function, see "Cross-National Perspectives on Multinational Companies and Employment Relations," special issue of ILR Review 66, no. 3 (2013): 547-587.

6. Ibid.

7. Information in this section was obtained through interviews with managers conducted over several years by Harry Katz.

8. Quoted in Locke, The Promise and Limits of Private Power, 49.

9. Ibid., 47-77.

10. See, for example, the forum on this topic in The Boston Review 38, no. 3 (May-June 2013): 12-29

11. Pablo L. Gradi, Trade Agreements and Their Relation to Labour Standards: The Current Situation, International Centre for Trade and Sustainable Development Issue Paper no. 3 (Geneva: International Centre for Trade and Sustainable Development, 2009), http://ictsd.org/ downloads/2011/12/tradc-agreements-and-their-relation-to-labour-standards.pdf.

12. Eli J. Kirschner, "Fast Track Authority and Its Implications for Labor Protection in Free Trade Agreements," Cornell International Law Joumal 44 (2011): 386-415.

13. Solidarity Center. "Justice for All: The Struggle for Worker Rights in Jordan," Solidarity Centcr, Washington, D.C., 2005, http://www.solidaritycenter.org/files/JordanFinal.pdf, accessed January 8, 2014.

14. Office of the United States Trade Representative, "U.S.-Colombia Trade Agreement," http://www.ustr.gov/uscolombiatpa.

15. "The U.S.-Colombia Labor Action Plan: Failing on the Ground," a staff report on behalf of U.S. Representatives George Miller and Jim McGovern to the Congressional Monitoring Group on Labor Rights in Colombia, Octobcr 2013, http://democrats.edworkforce .housc.gov/sites/democrats.edworkforce.house.gov/files/documents/Colombia\%20trip\%20 report $\% 20-\% 2010.29 .13 \% 20-\% 20$ formatted\%20-\%20FINAL.pdf.

16. Drusilla Brown, Rajeev Dchejia, and Raymond Robcrtson, "Is There an Efficiency Case for Intcrnational Labor Standards?" Tufts University working paper, July 2013, http:// www.freit.org/WorkingPapers/Papers/TradePolicyMultilateral/FREIT574.pdf. See also International Labour Organization and Better Factories Cambodia, "Thirtieth Synthesis Rcport on Working Conditions in Cambodia's Garment Sector and Statement of the Project Advisory Committee." 